\title{
Prooxidative-Antioxidative Balance of Cells in Different Types of Renal Replacement Therapy
}

\author{
Joanna Stępniewska ${ }^{a}$ Barbara Dołęgowska ${ }^{b}$ Marlena Popińskab Daria Sałatab \\ Marta Budkowskab Edyta Gołembiewska ${ }^{a} \quad$ Marek Myślak $^{a} \quad$ Maciej Domańskia \\ Małgorzata Marchelek-Myśliwiec ${ }^{a} \quad$ Kazimierz Ciechanowski ${ }^{a}$ \\ ${ }^{a}$ Department of Nephrology, Transplantology and Internal Medicine and ${ }^{\mathrm{b}}$ Department of Medical Analysis, \\ Pomeranian Medical University, Szczecin, Poland
}

\section{Key Words}

Chronic kidney disease · Dialysis · Oxidative stress · Free radicals

\begin{abstract}
Background: Patients suffering from chronic kidney disease (CKD) are exposed to increased oxidative stress and disturbances manifesting in the enzymatic and non-enzymatic antioxidative defence system. The object of the research was to assess the differences between conservative treatment, peritoneal dialysis and haemodialysis in moderating cellular antioxidative agents. Methods: The group examined comprised 145 patients. The activities of superoxide dismutase, catalase, glutathione peroxidase, glutathione reductase and glucose-6-phosphate dehydrogenase were obtained using kinetic methods. The spectrophotometric method established the concentrations of reduced glutathione, albumin, uric acid, glucose, total protein and lipids. Results: The type of treatment determined significant changes in antioxidative enzyme activities and concentrations of non-enzymatic antioxidative compounds. Conclusions: Peritoneal dialysis provides better antioxidant protection than other types of therapy in CKD and should be considered as first-choice treatment despite more metabolic disorders.
\end{abstract}

(c) 2014 S. Karger AG, Basel

\section{KARGER}

(c) 2014 S. Karger AG, Base

0253-5068/14/0371-0004\$39.50/0

E-Mail karger@karger.com

www.karger.com/bpu

\section{Introduction}

The prevalence of chronic kidney disease (CKD) is on the rise all over the world. It is related to prolonged life expectancy, better medical care and access to renal replacement therapy. In Poland the number of patients who qualify for dialysis treatment is increasing by $4-6 \%$ every year. Statistics show that in $2007,50 \%$ of the dialysed patients were over 65 years of age. The ageing of the society has resulted in a high morbidity due to diseases of civilization. The fastest growing group starting regular dialysis are those who suffer from diabetic kidney disease [1]. The ageing process with all its comorbidities alters body homeostasis. Impaired immunity and disturbances in repairing processes lead to intracellular damages, namely those that cause oxidation of macro- and micromolecular compounds, increased arteriosclerosis, mutations and carcinogenesis, collagen degradation, lower activity of transmembrane pumps, decreased enzyme activity, lower ATP concentration, higher platelet aggregation and changes in rheological properties of the blood. The dialysis therapy itself can exacerbate these processes by the generation of oxidative stress. However, the cells, especially erythrocytes, are equipped with an effective enzymatic and non-enzymatic antioxidant defence system

Dr. Joanna Stępniewska

Department of Nephrology, Transplantology and Internal Medicine Pomeranian Medical University, Powstancow Wielkopolskich 72 PL-70-111 Szczecin (Poland)

E-Mail asia_stepniewska@wp.pl 
Fig. 1. Main components of the antioxidative system. $\mathrm{ROOH}=$ Peroxide; $\mathrm{ROH}=$ oxide (see text for further abbreviations).

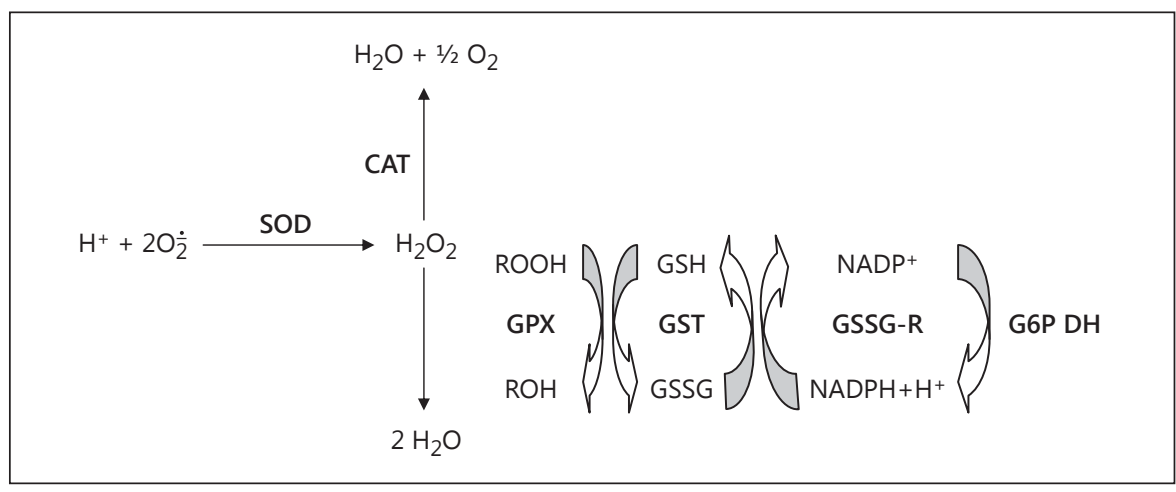

(fig. 1). The most important antioxidative enzymes are superoxide dismutase (SOD), catalase (CAT), glutathione peroxidase (GPX), glutathione reductase (GSSG-R), glutathione transferase (GST) and glucose-6-phosphate dehydrogenase (G6PDH). The non-enzymatic free radical scavengers are carotenoids, vitamin $\mathrm{E}$, metal ionbinding proteins (albumin, ceruloplasmin, transferrin, ferritin) and compounds containing the SH group (glutathione, cysteine, homocysteine, coenzyme Q) [2-6].

Antioxidative enzymes cooperate in oxidative stress reduction. SOD is involved in a reaction eliminating superoxide radical $\left(\mathrm{O}_{2}{ }^{\circ}\right)$ and generating hydrogen peroxide $\left(\mathrm{H}_{2} \mathrm{O}_{2}\right)$, which is subsequently decomposed by CAT or GPX. GPX uses reduced glutathione (GSH) and transforms it into the oxidized form. Reduced GSH, necessary for that reaction, is delivered due to GSSG-R, which reduces GSSG to GSH using the nicotinamide adenine dinucleotide phosphate-reduced form (NADPH+). The source of reactive equivalents $(\mathrm{NADPH}+)$ in erythrocytes is the reaction catalysed by G6PDH - the main enzyme of hexose monophosphate shunt $[7,8]$. The non-enzymatic antioxidant compounds in the presence of antioxidant enzymes determine a target against reactive oxygen species (ROS). The most important composites of total antioxidant capacity of blood plasma are uraemic acid and albumin [9-18].

In the present article we report the influence of different types of kidney replacement therapy on the antioxidant status in patients.

\section{Materials and Methods}

The study was performed at the Department of Nephrology, Transplantology and Internal Medicine of Pomeranian Medical University, Szczecin, Poland. The group examined comprised 145 patients - 54 on haemodialysis (HD), 23 on peritoneal dialysis (PD) and 68 patients on conservative treatment with CKD stage
3-5 (CKD3-5) according to the KDIGO guidelines. The general characteristics of the examined group included gender, age, time since first dialysis, estimated glomerular filtration rate (eGFR), residual renal function (RRF), causes of CKD in each group, comorbidities, and medications like erythropoietin, iron, antihypertensives and statins (table 1). RRF was defined as urine output $>500$ $\mathrm{ml} / 24 \mathrm{~h}$. The duration of dialysis treatment did not differ significantly between patients on PD and HD. The selected biochemical parameters of the examined group and differences between them are shown in table 2 .

Inclusion criteria for the study were as follows: diagnosis of $\mathrm{CKD}$, regular $\mathrm{HD}$ or $\mathrm{PD}$ for at least 6 months before starting the study, or predialysis CKD3-5 according to KDIGO guidelines. Dialysis adequacy was defined by a Kt/V ratio ranging from 1.2 for HD patients to 1.7 for those on PD. The standard dialysis concentrate and standard PD fluid were used. All patients on PD were treated with the same dialysis fluid containing glucose of 1.5 and $2.5 \%$ in a proportion of 1:1. Thirteen patients had continuous ambulatory PD and 10 automatic PD. HD was scheduled 3 times/ week (12 h weekly) using polysulphone dialysers. Treatment with antiplatelet medication, malnutrition-inflammation-atherosclerosis syndrome, active inflammation, metastatic cancer and cigarette smoking were considered exclusion criteria from the research. Patients did not undergo any blood transfusions 1 month before the study. The study was approved by the Bioethical Committee of Pomeranian Medical University, Szczecin, Poland. All subjects gave informed consent. Blood was taken directly from the arteriovenous fistula or dialysis catheter in HD patients directly before (pre-HD) and immediately after the HD (post-HD) session. In $\mathrm{PD}$ and predialysis patients blood from the peripheral vein was collected during a routine visit.

The activity of erythrocyte antioxidative enzymes (SOD, CAT, GPX, GSSG-R, G6PDH) was assessed using kinetic methods. Values obtained were calculated per gram of haemoglobin $(\mathrm{Hb})$. The GSH concentration was examined according to a spectrophotometric method directly after sample collection. The concentrations of albumin, uric acid, total protein and lipids were measured using spectrophotometric methods and ready-made reagents (AquaMed, Lodz, Poland).

\section{Statistical Analysis}

The results are presented as arithmetic mean \pm SD and median (upper and lower quartile). Shapiro-Wilk's test showed that the 
distributions of the results obtained were not normal, therefore non-parametric tests were used: Wilcoxon's pair test for dependent variables, and the ANOVA Kruskal-Wallis rank test and Mann-Whitney $U$ test for independent variables. The qualitative differences were assessed using the $\chi^{2}$ test. Spearman's rank test was used to establish the correlations between measured values. The statistical significance was assumed at $\mathrm{p}<0.05$.

\section{Results}

The mean total protein concentration in patients on PD was significantly higher than in the pre- $\mathrm{HD}(\mathrm{p}=0.001)$ and post-HD ( $\mathrm{p}=0.0001)$ samples, but significantly lower compared to CKD3-5 patients $(\mathrm{p}=0.0001)$. The HD session itself did not change the total protein concentration. The total cholesterol and HDL cholesterol levels were decreased, but triglycerides were significantly higher in the $\mathrm{PD}$ group compared to $\mathrm{HD}$ and $\mathrm{CKD} 3-5$ patients. The glucose concentration did not differ significantly between CKD3-5 patients and the PD group. HD patients had the lowest glucose plasma level, with a significant decrease after the HD procedure $(\mathrm{p}=0.01)$ (table 2$)$.

\section{Enzymatic Antioxidant System}

The results of enzyme activity are shown in table 3 . SOD activity was significantly higher in HD patients immediately after the HD session compared to pre-HD values $(\mathrm{p}=0.0001)$. SOD activity in PD patients was significantly lower than in the post-HD samples. CKD3-5 patients had a different SOD activity compared to the HD group, both before $(\mathrm{p}=0.00001)$ and after the HD session $(\mathrm{p}=0.0001)$.

The mean values of CAT activity were significantly different among the groups. The highest CAT activity was in CKD3-5 patients. The HD session caused a significant decrease in CAT activity $(\mathrm{p}=0.005)$. In PD, CAT was significantly higher than in the post-HD samples $(\mathrm{p}=0.04)$ and significantly lower compared with the CKD3-5 group $(\mathrm{p}=0.01)$.

In PD patients GPX activity reached $14.87 \pm 8.44 \mathrm{U} / \mathrm{g}$ $\mathrm{Hb}$ and was significantly different to that in post-HD patients $(\mathrm{p}=0.03)$ and CKD3-5 patients $(\mathrm{p}=0.04)$. As in the case of CAT, the highest values of GPX were assessed in the CKD3-5 group, but the lowest in post-HD patients. These activities differ significantly $(\mathrm{p}=0.0001)$. The HD procedure caused a significant decrease in GPX activity $(\mathrm{p}=0.02)$.

The activity of GST was lowest in the PD group compared to the other groups but the difference was significant only in comparison to post-HD patients $(\mathrm{p}=0.05)$.
Table 1. General characteristics of the groups examined

\begin{tabular}{|c|c|c|c|}
\hline & $\begin{array}{l}\mathrm{PD} \\
(\mathrm{n}=23)\end{array}$ & $\begin{array}{l}\mathrm{HD} \\
(\mathrm{n}=54)\end{array}$ & $\begin{array}{l}\text { CKD3-5 } \\
(n=68)\end{array}$ \\
\hline \multicolumn{4}{|l|}{ Demographics } \\
\hline Male/female & $13 / 10$ & $34 / 20$ & $38 / 30$ \\
\hline Age, years & $46 \pm 16$ & $61 \pm 17^{*}$ & $65 \pm 20^{*}$ \\
\hline Time since first $\mathrm{HD}$, months & $17 \pm 14$ & $21 \pm 13$ & 0 \\
\hline $\mathrm{eGFR}, \mathrm{ml} / \mathrm{min} / 1.73 \mathrm{~m}^{2}$ & $<15$ & $<15$ & $21.8 \pm 7.8$ \\
\hline $\mathrm{RRF}(>500 \mathrm{ml} / 24 \mathrm{~h})$ & 23 & 9 & 68 \\
\hline \multicolumn{4}{|l|}{ Causes of CKD } \\
\hline Hypertension & 5 & 21 & 17 \\
\hline Diabetes & 6 & 15 & 14 \\
\hline Glomerulonephritis & 6 & 8 & 14 \\
\hline Kidney cancer & - & 2 & 6 \\
\hline Vesicoureteral reflux & 1 & 2 & 5 \\
\hline ADPKD & - & 2 & 8 \\
\hline Amyloidosis & - & 1 & - \\
\hline Neurogenic bladder & 2 & - & - \\
\hline Other & 3 & 3 & 4 \\
\hline \multicolumn{4}{|l|}{ Comorbidities } \\
\hline Ischaemic heart disease & 11 & 39 & 35 \\
\hline Hypertension & 10 & 24 & 30 \\
\hline Large-vessel atherosclerosis & 3 & 20 & 17 \\
\hline COPD & 2 & 8 & 10 \\
\hline Liver cirrhosis & - & 4 & 6 \\
\hline Urolithiasis & 1 & 7 & 11 \\
\hline Gout & 2 & 9 & 12 \\
\hline $\begin{array}{l}\text { Cancer in medical history } \\
\text { (except for kidney) }\end{array}$ & - & 3 & 3 \\
\hline \multicolumn{4}{|l|}{ Medications } \\
\hline Erythropoietin & 16 & 54 & 10 \\
\hline Iron & 23 & 54 & 37 \\
\hline Antihypertensives & 15 & 45 & 47 \\
\hline Statins & 11 & 19 & 31 \\
\hline
\end{tabular}

ADPKD = Autosomal dominant polycystic kidney disease; COPD $=$ chronic obstructive pulmonary disease. ${ }^{*} \mathrm{p}=0.01$; statistically significant value between the PD and $\mathrm{HD}$ or the PD and CKD groups.

The activity of G6PDH reached the lowest value in pre-HD patients and significantly increased after the HD session $(\mathrm{p}=0.01)$. PD patients had the highest activity of this enzyme which differs significantly from that in the pre-HD samples.

The average activity of GSSG- $\mathrm{R}$ was significantly higher in the PD group compared to the HD group, both before and after the HD session. The highest value of GSSG$\mathrm{R}$ was obtained in CKD3-5 patients and differs significantly from that in post-HD patients. The HD itself did not significantly impact GSSG-R activity. 
Table 2. Concentrations of basic plasma biochemical parameters of the groups examined [average \pm SD, median (LQ; UQ)]

\begin{tabular}{|c|c|c|c|c|c|c|}
\hline & $\begin{array}{l}P D \\
(n=23)\end{array}$ & $\begin{array}{l}\text { Pre-HD } \\
(\mathrm{n}=54)\end{array}$ & $\begin{array}{l}\text { Post-HD } \\
(\mathrm{n}=54)\end{array}$ & $\begin{array}{l}\text { CKD3-5 } \\
(n=68)\end{array}$ & $\mathrm{p}^{*}$ & $\mathrm{p}^{* *}$ \\
\hline Total protein, g/dl & $\begin{array}{l}5.82 \pm 0.29 \\
5.78(5.69 ; 6.02)\end{array}$ & $\begin{array}{l}5.49 \pm 0.47 \\
5.48(5.18 ; 5.72)\end{array}$ & $\begin{array}{l}5.74 \pm 0.89 \\
5.58(5.22 ; 6.02)\end{array}$ & $\begin{array}{l}6.82 \pm 0.76 \\
6.59(6.29 ; 7.41)\end{array}$ & 0.0001 & SI \\
\hline Glucose, mg/dl & $\begin{array}{l}113.3 \pm 24.5 \\
112.8(90.2 ; 132.1)\end{array}$ & $\begin{array}{l}111.3 \pm 33.4 \\
104.5(91.5 ; 121.4)\end{array}$ & $\begin{array}{l}101.8 \pm 27.3 \\
93.38(85.0 ; 107.7)\end{array}$ & $\begin{array}{l}125.6 \pm 47.9 \\
111.5(97.2 ; 143.2)\end{array}$ & 0.001 & 0.01 \\
\hline HDL cholesterol, mg/dl & $\begin{array}{l}47.8 \pm 3.9 \\
48.5(45.3 ; 49.2)\end{array}$ & $\begin{array}{l}53.2 \pm 8.1 \\
53.2(45.7 ; 59.1)\end{array}$ & $\begin{array}{l}60.5 \pm 10.6 \\
59.8(53.5 ; 68.9)\end{array}$ & $\begin{array}{l}66.4 \pm 11.0 \\
66.7(59.7 ; 73.4)\end{array}$ & 0.00001 & 0.00001 \\
\hline Triglycerides, mg/dl & $\begin{array}{l}197.7 \pm 31.7 \\
200.0(175.5 ; 213.6)\end{array}$ & $\begin{array}{l}161.8 \pm 56.0 \\
146.7(133.0 ; 175.5)\end{array}$ & $\begin{array}{l}165.4 \pm 69.4 \\
146.7(129.3 ; 175.5)\end{array}$ & $\begin{array}{l}163.7 \pm 36.2 \\
158.5(135.4 ; 185.4)\end{array}$ & 0.0001 & SI \\
\hline
\end{tabular}

$\mathrm{SD}=$ Standard deviation; $\mathrm{LQ}=$ lower quartile; $\mathrm{UQ}=$ upper quartile; $\mathrm{SI}=$ statistically insignificant. * $\mathrm{p}=$ Level of significance for differences between groups using the ANOVA Kruskal-Wallis test; ${ }^{* *} \mathrm{p}=$ level of significance for differences in pre- and post-HD values using the Wilcoxon test.

Table 3. Activity of erythrocytes' antioxidative enzymes of the patients examined [average \pm SD, median (LQ; UQ)]

\begin{tabular}{|c|c|c|c|c|c|c|}
\hline & $\begin{array}{l}\mathrm{PD} \\
(\mathrm{n}=23)\end{array}$ & $\begin{array}{l}\text { Pre-HD } \\
(\mathrm{n}=54)\end{array}$ & $\begin{array}{l}\text { Post-HD } \\
(\mathrm{n}=54)\end{array}$ & $\begin{array}{l}\text { CKD3-5 } \\
(n=68)\end{array}$ & $\mathrm{p}^{*}$ & $\mathrm{p}^{* *}$ \\
\hline $\mathrm{SOD}, \mathrm{U} / \mathrm{g} \mathrm{Hb}$ & $\begin{array}{l}484.0 \pm 181.6 \\
432.8(339.0 ; 633.5)\end{array}$ & $\begin{array}{l}382.5 \pm 133.3 \\
395.6(346.6 ; 453.7)\end{array}$ & $\begin{array}{l}606.7 \pm 98.2 \\
622.2(543.4 ; 670.2)\end{array}$ & $\begin{array}{l}509.0 \pm 143.5 \\
497.1(421.8 ; 574.9)\end{array}$ & 0.00001 & 0.00001 \\
\hline $\mathrm{CAT}, \mathrm{U} / \mathrm{g} \mathrm{Hb}$ & $\begin{array}{l}194.8 \pm 73.7 \\
185.8(162.5 ; 209.9)\end{array}$ & $\begin{array}{l}189.1 \pm 66.6 \\
198.1(160.7 ; 224.6)\end{array}$ & $\begin{array}{l}159.9 \pm 43.3 \\
162.4(138.8 ; 192.2)\end{array}$ & $\begin{array}{l}228.6 \pm 71.5 \\
227.1(190.7 ; 253.4)\end{array}$ & 0.0001 & 0.005 \\
\hline GST, U/g Hb & $\begin{array}{l}3.02 \pm 1.35 \\
2.95(2.35 ; 3.33)\end{array}$ & $\begin{array}{l}3.44 \pm 2.12 \\
2.99(2.28 ; 4.29)\end{array}$ & $\begin{array}{l}3.79 \pm 1.66 \\
3.13(2.71 ; 4.66)\end{array}$ & $\begin{array}{l}3.86 \pm 2.58 \\
3.32(2.53 ; 4.47)\end{array}$ & SI & SI \\
\hline G6PDH, U/g Hb & $\begin{array}{l}8.99 \pm 3.36 \\
8.15(7.06 ; 11.02)\end{array}$ & $\begin{array}{l}7.27 \pm 1.66 \\
7.24(6.13 ; 8.07)\end{array}$ & $\begin{array}{l}8.23 \pm 2.31 \\
7.87(6.65 ; 9.26)\end{array}$ & $\begin{array}{l}8.03 \pm 3.09 \\
7.61(6.08 ; 8.67)\end{array}$ & 0.02 & 0.01 \\
\hline
\end{tabular}

$\mathrm{SD}=$ Standard deviation; $\mathrm{LQ}=$ lower quartile; $\mathrm{UQ}=$ upper quartile; $\mathrm{SI}=$ statistically insignificant. $* \mathrm{p}=$ Level of significance for differences between groups using the ANOVA Kruskal-Wallis test; ${ }^{* *} \mathrm{p}=$ level of significance for differences in pre- and post-HD values using the Wilcoxon test.

\section{Non-Enzymatic Antioxidant System}

The parameters of the non-enzymatic antioxidant system are shown in table 4 . The highest concentration of GSH was observed in PD patients and differs significantly from those of the HD group, both before $(\mathrm{p}=0.01)$ and after $(\mathrm{p}=0.00001)$ the HD session, and the CKD3-5 group ( $\mathrm{p}=0.002)$. The dialysis procedure caused a significant decrease in GSH concentration.

An average albumin concentration was highest in the $\mathrm{PD}$ group and differs significantly from the pre-HD $(\mathrm{p}=$ $0.01)$ and post-HD ( $p=0.00001)$ samples. The significantly lowest values were obtained in CKD3-5 patients 
Table 4. Components of non-enzymatic erythrocytes and the plasma antioxidative system of the patients examined [average \pm SD, median (LQ; UQ)]

\begin{tabular}{|c|c|c|c|c|c|c|}
\hline & $\begin{array}{l}\mathrm{PD} \\
(\mathrm{n}=23)\end{array}$ & $\begin{array}{l}\text { Pre-HD } \\
(\mathrm{n}=54)\end{array}$ & $\begin{array}{l}\text { Post-HD } \\
(\mathrm{n}=54)\end{array}$ & $\begin{array}{l}\text { CKD3-5 } \\
(n=68)\end{array}$ & $\mathrm{p}^{*}$ & $\mathrm{p}^{* *}$ \\
\hline $\mathrm{GSH}, \mu \mathrm{mol} / \mathrm{g} \mathrm{Hb}$ & $\begin{array}{l}35.12 \pm 15.93 \\
32.34(25.49 ; 46.96)\end{array}$ & $\begin{array}{l}28.13 \pm 23.01 \\
19.25(13.21 ; 30.40)\end{array}$ & $\begin{array}{l}17.66 \pm 18.05 \\
14.62(12.89 ; 17.33)\end{array}$ & $\begin{array}{l}23.84 \pm 9.83 \\
22.20(16.25 ; 30.08)\end{array}$ & 0.00001 & 0.0003 \\
\hline Albumin, g/dl & $\begin{array}{l}4.20 \pm 0.72 \\
4.30(3.80 ; 4.80)\end{array}$ & $\begin{array}{l}3.50 \pm 0.52 \\
3.40(3.11 ; 3.83)\end{array}$ & $\begin{array}{l}3.43 \pm 0.66 \\
3.21(3.00 ; 3.67)\end{array}$ & $\begin{array}{l}3.10 \pm 0.39 \\
3.10(2.88 ; 3.30)\end{array}$ & 0.00001 & SI \\
\hline Uric acid, mg/dl & $\begin{array}{l}5.12 \pm 0.58 \\
4.89(4.65 ; 5.67)\end{array}$ & $\begin{array}{l}5.18 \pm 1.39 \\
4.89(4.56 ; 5.44)\end{array}$ & $\begin{array}{l}5.02 \pm 1.89 \\
4.56(3.85 ; 5.33)\end{array}$ & $\begin{array}{l}5.37 \pm 0.85 \\
5.28(4.89 ; 5.56)\end{array}$ & 0.0001 & SI \\
\hline
\end{tabular}

$\mathrm{SD}=$ Standard deviation; $\mathrm{LQ}=$ lower quartile; $\mathrm{UQ}=$ upper quartile; $\mathrm{SI}=$ statistically insignificant. $* \mathrm{p}=$ Level of significance for differences between groups using the ANOVA Kruskal-Wallis test. ${ }^{* *} \mathrm{p}=$ level of significance for differences in pre- and post-HD values using the Wilcoxon test.

$(\mathrm{p}=0.00001)$. The uric acid concentrations obtained in CKD3-5 patients were significantly higher than in pre$\mathrm{HD}(\mathrm{p}=0.005)$ and post-HD $(\mathrm{p}=0.0001)$ patients and in the PD group $(\mathrm{p}=0.0001)$. PD patients had significantly higher concentrations compared to post-HD patients $(\mathrm{p}=0.02)$.

Spearman's rank test established the correlations between measured parameters. In PD patients some negative correlations were observed between antioxidant enzymes: SOD and CAT $(\mathrm{R}=-49, \mathrm{p}=0.02)$, GPX and GST $(\mathrm{R}=-0.46, \mathrm{p}=0.03)$, and GST and GSSG-R $(\mathrm{R}=-0.43$, $\mathrm{p}=0.04)$. The duration of dialysis treatment is correlated negatively with the GSH concentration in erythrocytes of PD patients $(\mathrm{R}=-0.42, \mathrm{p}=0.05)$ and in the HD group after the dialysis session $(\mathrm{R}=-0.57, \mathrm{p}=0.01)$. The activity of CAT in pre-HD patients and at the time of dialysis therapy is also negatively correlated $(\mathrm{R}=-0.45, \mathrm{p}=0.04)$. Analysis of correlations and regression models showed no dependence of age and RRF on the antioxidative system components of the patients.

\section{Discussion}

Patients suffering from CKD are exposed to increased oxidative stress which is related to uraemia and the dialysis procedure itself. According to the stage of CKD and type of renal replacement therapy, they may present different disturbances in antioxidative mechanisms. It is known that patients undergoing regular HD manifest a high amount of oxidative stress indicators due to several factors like bioincompatible dialysis membranes, non- sterile dialysate, poor quality of dialysis water, the backleak of contaminants across the dialysis membrane, etc. Oxidative stress causes neutrophil degranulation and the production of inflammatory mediators. The number of neutrophils drops suddenly during the first $30 \mathrm{~min}$ of HD and contributes to a huge formation of ROS. Other reasons for increased oxidative stress are lack of certain vitamins and microelements (C, E, selenium), advanced age of patients, high prevalence of diabetes, chronic inflammatory state, excessive parenteral iron administration, anaemia, etc. Oxidative stress links to malnutrition-inflammation-atherosclerosis syndrome and contributes to increased cardiovascular morbidity and mortality in patients with CKD. The type of renal replacement therapy can influence the outcome and possibility of subsequent kidney transplantation. In our study we compare the influence of different types of renal replacement therapy on the antioxidant defence system of patients.

SOD is considered to be the most important antioxidative enzyme. It eliminates superoxide anion which is highly reactive and may cause tissue damage due to proliferation and apoptosis of endothelial cells. The effective antioxidative system of healthy people can neutralize even $1.75 \mathrm{~kg}$ of these radicals daily [19]. In the present research there were no significant differences of SOD activity between patients on $\mathrm{PD}$, conservatively treated patients and HD patients before the HD session. However, the HD procedure caused a significant increase in SOD activity as measured after the HD session. Similar results were described by Hernández de Rojas and Mateo [20] and Durak et al. [21]. Coaccioli et al. [22] showed a higher SOD activity in dialysed patients than in healthy con- 
trols, but no differences between PD and HD. In this parameter Ceballos-Picot et al. [23] did not obtain differences between a control and dialysed group. Naga et al. [24] examined the patients before and 4 weeks after starting dialysis therapy. The results of this research showed a decrease in SOD activity during both HD and PD. The patients in our study were over 6 months on dialysis.

CAT and GPX prevent the accumulation of $\mathrm{H}_{2} \mathrm{O}_{2}$. In our study the highest activity of CAT was obtained in conservatively treated CKD3-5 patients. The same results were obtained by Martin-Mateo et al. [25]; in their research, CAT activity was significantly higher in nondialysed patients with CKD compared to healthy controls. Patients on PD had a similar activity of CAT compared to conservatively treated patients and HD patients before the dialysis session. The HD procedure caused a significant decrease in CAT activity, which differs significantly from the PD group. The study by Durak et al. [21] confirms our findings. Some authors described an increased activity of CAT in HD patients compared to healthy controls $[20,26]$. In the present study the PD group was characterized by the negative correlation between SOD and CAT activities, but in HD patients a positive correlation occurred between these enzymes. This can indicate the involvement of many antioxidative enzymes due to the high amount and diversity of ROS produced.

GPX is involved in GSH metabolism; its role is to protect from $\mathrm{H}_{2} \mathrm{O}_{2}$ and lipid peroxides. The reduced GSH is necessary for GPX action [27]. A lower GSH concentration leads to a decreased GPX activity. In CKD excessive oxidative stress results in a reduction of GPX activity and enhancement of arteriosclerosis and cardiovascular diseases due to lipid peroxidation [28]. Reports about GPX activity in CKD are inconclusive. Some authors described a positive impact of $\mathrm{PD}$, but others did not find differences compared with HD [21, 23, 24, 28-34]. Our study showed that renal replacement therapy negatively influences GPX activity. CKD3-5 patients have significantly higher values. In addition, the HD process causes a significant decrease in GPX activity. Similar results were obtained by Santangelo et al. [27] and El-Rashidy et al. [35].

Galii et al. [33] described a higher expression of genes coding GST during oxidative stress. In CKD a shift of the prooxidative-antioxidative equilibrium towards the oxidation reactions is observed, so we expected higher activity of GST [25]. The present results confirm this premise. In our study there were no significant differences between GST activities among the whole examined groups; however, it was above the normal range. Some authors showed a higher activity of GST in HD than in PD patients [3335]. The HD procedure did not influence this enzyme activity. The negative correlation between GST and GPX activity in PD patients may indicate a competition for a common substrate. Some authors claim that GST activity depends on the stage of kidney disease and may become a marker of uraemic toxicity and kidney graft function $[33,34,36,37]$.

GSSG- $\mathrm{R}$ is an enzyme dependent on the availability of $\mathrm{NADPH}+\mathrm{H}^{+}$. The increase of GSSG (the oxidized form of GSH) concentration or lower synthesis of $\mathrm{NADPH}+\mathrm{H}^{+}$ due to decreased G6PDH activity may inhibit the GSSG$\mathrm{R}$ action. It results in a reduced regeneration of GSH and an inadequate function of the antioxidative system [38]. A decreased activity of GSSG-R is frequently observed in both conservatively treated patients and HD patients. In our study the activity of GSSG-R of HD patients was significantly lower compared to that of the PD and CKD3-5 groups. Similar results were obtained by Santangelo et al. [27] and Ahmadpoor et al. [28]. Ceballos-Picot et al. [23] showed increased activities of GSSG-R without significant differences between HD and PD patients.

$\mathrm{G} 6 \mathrm{PDH}$ is one of the enzymes responsible for the maintenance of an adequate $\mathrm{NADPH}+\mathrm{H}^{+}$concentration in the cell. The lower activity of G6PDH results in an increased susceptibility to haemolysis during contact with the dialysis membrane. There is a proven connection between oxidative damage of erythrocytes and a lack of $\mathrm{NADPH}+\mathrm{H}^{+}[7,39]$. In our study no significant differences in G6PDH activity were observed between PD group, pre-HD samples and CKD3-5 patients. HD treatment caused a significant increase in this enzyme activity. Similar results were described by Paşaoğlu et al. [32] and Alhamdani et al. [40]. Other authors also showed that the activity of G6PDH depends on the glucose content in the dialysate. The activity was the highest in the presence of glucose [41-43].

The GSH thiol group (SH) is oxidized to GSSG by a reaction with xenobiotics, $\mathrm{H}_{2} \mathrm{O}_{2}$, organic peroxides and free radicals. Uraemic toxins and highly reactive GPX are also oxidizing substances utilizing GSH [27]. Its concentration in healthy people is significantly higher compared to CKD patients [23-25, 32, 41, 44, 45]. In the present study PD patients had significantly higher concentrations of GSH than the HD and CKD3-5 groups. Similar results were obtained by Tarng et al. [46]. During the HD session a significant decrease in GSH concentration was observed [47]. This may be caused by excessive oxidizing of GSH and a lack of its reduced form or low activity of $\gamma$-glutamylcysteine, which is necessary for regaining GSH [47]. 
The longer the time since the first dialysis, the lower the GSH concentrations obtained.

The albumin concentration in PD patients is significantly higher than in the HD and CKD3-5 groups. Zachara et al. [48] estimated a linear decrease in total protein and albumin along with progression in kidney insufficiency. A higher urinary albumin loss was noted in diabetic patients [49]. The concentration of albumin and total protein in PD patients with diabetes is significantly lower than in patients without this comorbidity [50]. The authors suspect that it is caused by a greater permeability of the diabetic peritoneum.

The uric acid concentration was significantly lower in PD patients compared to the CKD3-5 group, but significantly higher than in patients examined after the HD session. HD treatment is very effective in removing this compound from the blood plasma. Uric acid represents the total plasma antioxidative capacity. Its increased synthesis in CKD is connected with the production of super- oxide anion and $\mathrm{H}_{2} \mathrm{O}_{2}$, which may play an important role in the pathogenesis of the disease [13].

In conclusion, $\mathrm{PD}$ provides better antioxidant protection than HD and should be considered the first-choice treatment of CKD as often as possible. Unfortunately, it is connected with some metabolic disorders like hypertriglyceridaemia and higher levels of uric acid. In order to avoid such abnormalities we should use fluids with low glucose concentrations or without glucose. PD gives better candidates for kidney transplantation and, in longterm treatment, can minimalize the complications resulting from excessive oxidative stress, especially cardiovascular diseases.

\section{Acknowledgment}

This study was supported by a grant awarded by the Polish National Science Center (2011/01/B/NZ5/04235).

\section{References}

1 Eggers PW: Mortality rates among dialysis patients in Medicare's End-Stage Renal Disease Program. Am J Kidney Dis 1990;15:414421.

2 Del Vecchio L, Locatelli F, Carini M: What we know about oxidative stress in patients with chronic kidney disease on dialysis-clinical effects, potential treatment and prevention. Semin Dial 2011;24:56-64

3 Rahman K: Studies on free radicals, antioxidants, and co-factors. Clin Interv Aging 2007; 2:219-236.

4 Modlinger PS, Wilcox CS, Aslam S: Nitric oxide, oxidative stress, and progression of chronic renal failure. Semin Nephrol 2004;24: 354-365.

5 Sies H: Oxidative stress: oxidants and antioxidants. Exp Physiol 1997;82 291-295.

6 Mekki K, Taleb W, Bouzidi N, Kaddous A, Bouchenak M: Effect of hemodialysis and peritoneal dialysis on redox status in chronic renal failure patients: a comparative study. Lipids Health Dis 2010;9:93.

7 Peters AL, Van Noorden C: Glucose-6-phosphate dehydrogenase deficiency and malaria: cytochemical detection of heterozygous G6PD deficiency in women. J Histochem Cytochem 2009;57:1003-1011.

8 De Flora A, Morelli A, Giuliano F: Human erythrocyte glucose 6-phosphate dehydrogenase. Content of bound coenzyme. Biochem Biophys Res Commun 1974;59:406-413.

-9 Djousse L, Kenneth JR, Cupples A, Arnett DK, Ellison RC: Relation between serum albumin and carotid atherosclerosis. The NHLBI Family Heart Study. Stroke 2003;34:53-57.
10 Ferrucci L, Harris TB, Guralnik JM, Tracy RP, Corti MC, Cohen HJ: Serum IL-6 level and the development of disability in older persons. J Am Geriatr Soc 1999;47:639-646.

11 Bito R, Shikano T, Kawabata H: Isolation and characterization of denaturated serum albumin from rats with endotoxicosis. Biochim Biophys Acta 2003;1646:100-111.

12 Bito R, Hino S, Baba A, Tanaka M, Watabe H, Kawabata H: Degradation of oxidative stressinduced denatured albumin in rat liver endothelial cells. Am J Physiol Cell Physiol 2005; 289:C531-C542.

13 Dawson J, Walters M: Uric acid and xanthine oxidase: future therapeutic targets in the prevention of cardiovascular disease? Br J Clin Pharmacol 2006;62:633-644.

14 Kanelis J, Feig DI, Johnson RJ: Does asymptomatic hyperuricaemia contribute to the development of renal and cardiovascular disease? An old controversy renewed. Nephrology 2004;9:394-399.

15 Enomoto A, Kimua H, Chairoungdua A, Shigeta Y, Jutabha P, Cha SH: Molecular identification of a renal urate anion exchanger that regulates blood urate levels. Nature 2002;23 447-452.

16 Whiteman M, Ketsawatsakul U, Halliwell B: A reassessment of the peroxynitrite scavenging activity of uric acid. Ann NY Acad Sci 2002;962:242-259.

17 Waring WS: Uric acid: an important antioxidant in acute ischaemic stroke. QJM 2002;95 691-693.

18 Nieto FJ, Iribarren C, Gross MD, Comstock GW, Cutler RG: Uric acid and serum antioxi- dant capacity: a reaction to atherosclerosis? Atherosclerosis 2000;148:131-139.

19 Pandey NR, Kaur G, Chandra M, Sanwal GG Misra MK: Enzymatic oxidant and antioxidants of human blood platelets in unstable angina and myocardial infarction. Int J Cardiol 2000;76:33-38.

20 Hernández de Rojas A, Mateo MC: Superoxide dismutase and catalase activities in patients undergoing hemodialysis and continuous ambulatory peritoneal dialysis. Ren Fail 1996;18:937-946.

-21 Durak I, Akyol O, Başeşme E, Canbolat O, Kavutçu M: Reduced erythrocyte defense mechanisms against free radical toxicity in patients with chronic renal failure. Nephron 1994;66: 76-80.

22 Coaccioli S, Standoli ML, Biondi R, Panaccione A, Landucci P, Del Giorno R, Paladini A, Standoli M, Puxeddu A: Assessment of the oxidative stress markers in patients with chronic renal insufficiency undergoing dialysis treatment. Clin Ter 2010;161:441444.

23 Ceballos-Picot I, Witko-Sarsat V, MeradBoudia M, Nguyen AT, Thévenin M, Jaudon MC, Zingraff J, Verger C, Jungers P, Descamps-Latscha B: Glutathione antioxidant system as a marker of oxidative stress in chronic renal failure. Free Radic Biol Med 1996;21:845-853.

24 Naga S, Ellakkany S, Barghash A, Eldeep E, Fawzy R: Effect of peritoneal dialysis and hemodialysis on oxidation end products in endstage renal disease patients. Bull Alex Fac Med 2007;43:103-104. 
25 Martin-Mateo MC, Sanchez-Portugal M, Iglesias S, de Paula A, Bustamante J: Clinical study: oxidative stress in chronic renal failure. Ren Fail 1999;21:155-167.

-26 Knap B, Prezelj M, Buturovi-Ponikvar J, Ponikvar R, Bren AF: Antioxidant enzymes show adaptation to oxidative stress in athletes and increased stress in hemodialysis patients. Ther Apher Dial 2009;13:300-305.

-27 Santangelo F, Witko-Sarsat V, Drüeke T, Descamps-Latscha B: Restoring glutathione as a therapeutic strategy in chronic kidney disease. Nephrol Dial Transplant 2004;19:19511955.

28 Ahmadpoor P, Eftekhar E, Nourooz-Zadeh J, Servat H, Makhdoomi K, Ghafari A: Glutathione, glutathione-related enzymes, and total antioxidant capacity in patients on maintenance dialysis. Iran J Kidney Dis 2009;3:2227.

29 Yonova D, Trendafilov I, Papazov V, Stanchen I, Zidarov R, Antonov S: Comparative study of oxidative stress in peritoneal dialysis and hemodialysis patients. Hoppokratia 2004;8: 172-174.

-30 Ozden M, Maral H, Akaydin D, Cetinalp P, Kalender B: Erythrocyte glutathione peroxidase activity, plasma malondialdehyde and erythrocyte glutathione levels in hemodialysis and CAPD patients. Clin Biochem 2002;35: 269-273.

- 31 Yoshimura S, Suemizu H, Nomoto Y, Sakai H, Katsuoka Y, Kawamura N, Moriuchi T: Plasma glutathione peroxidase deficiency caused by renal dysfunction. Nephron 1996;73:207211.

32 Paşaoğlu H, Muhtaroğlu S, Güneş M, Utaş C: The change of glutathione dependent antioxidant mechanism in patients with chronic renal disease by hemodialysis. Turk J Med Sci 1998;28:75-78.

33 Galli F, Rovidati S, Benedetti S, Buoncristiani U, Covarelli C, Floridi A, Canestrari F: Overexpression of erythrocyte glutathione Stransferase in uremia and dialysis. Clin Chem 1999;45:1781-1788.
Dessì M, Noce A, Dawood KF, Galli F, Taccone-Gallucci M, Fabrini R, Bocedi A, Massoud R, Fucci G, Pastore A, Manca di Villahermosa S, Zingaretti V, Federici G, Ricci G: Erythrocyte glutathione transferase: a potential new biomarker in chronic kidney diseases which correlates with plasma homocysteina. Amino Acids 2012;43:347-354.

35 El-Rashidy FH, Al-Turk WA, Stohs SJ: Glutathione, glutathione reductase and glutathione S-transferase activities in erythrocytes and lymphocytes in chronic renal disease. Res Commun Chem Pathol Pharmacol 1984;44: 423-430.

36 Carmagnol F, Sinet PM, Rapin J, Jerome H: Glutathione-S-transferase of human red blood cells; assay, values in normal subjects and in two pathological circumstances: hyperbilirubinemia and impaired renal function. Clin Chim Acta 1981;117:209-217.

37 Kharbanda R, Lauder J, Thomson D, Gouldesbrough DR, Harrison DJ: Heterogeneity of glutathione S-transferase isoenzyme expression in renal disease. Nephrol Dial Transplant 1991;6:695-700.

38 Tandoğan B, Ulusu N: Kinetic mechanism and molecular properties of glutathione reductase. FABAD J Pharm Sci 2006;31:230237.

39 Beutler E: Glucose-6-phosphate dehydrogenase deficiency: a historical perspective. Blood 2008;111:16-24.

40 Alhamdani MS, Al-Najjar AF, Al-Kassir AH: The effect of hemodialysis and dialyzer biocompatibility on erythrocyte glutathione-defense system in chronic hemodialysis patients. Int J Artif Organs 2005;28:576-582.

41 Stepniewska J, Dolegowska B, Ciechanowski K, Kwiatkowska E, Millo B, Chlubek D: Erythrocyte antioxidant defense system in patients with chronic renal failure according to the hemodialysis conditions. Arch Med Res 2006;37:353-359.
42 Dolegowska B, Stepniewska J, Ciechanowski K, Safranow K, Millo E, Bober J, Chlubek D: Does glucose in dialysis fluid protect erythrocytes in patients with chronic renal failure? Blood Purif 2007;25:422-429.

43 Dolegowska B, Blogowski W, Domanski L: Association between the perioperative antioxidative ability of platelets and early posttransplant function of kidney allograft. A pilot study. PLoS One 2012;10:1371.

44 Ross EA, Koo LC, Moberly JB: Low whole blood and erythrocyte levels of glutathione in hemodialysis and peritoneal dialysis patients. Am J Kidney Dis 1997;30:489-494.

45 Nguyen-Khoa T, Massy ZA, De Bandt JP, Kebede M, Salama L, Lambrey G, Witko-Sarsat V, Drüeke TB, Lacour B, Thévenin M: Oxidative stress and haemodialysis: role of inflammation and duration of dialysis treatment, Nephrol Dial Transplant 2001;16: 335-340.

46 Tarng DC, Wen Chen T, Huang TP, Chen CL, Liu TY, Wei YH: Increased oxidative damage to peripheral blood leukocyte DNA in chronic peritoneal dialysis patients. J Am Soc Nephrol 2002;13:1321-1330.

47 Hemmati M, Kadkhodaee M, Zahmatkesh M, Mahdavi-Mazde M, Ghaznavi R, Mirershadi F: Blood antioxidant levels and alterations of serum calcium and $\mathrm{pH}$ in hemodialysis patients. Tehran Univ Med J 2008;66:12-17.

48 Zachara BA, Salak A, Koterska D, Manitius J, Wasowicz W: Selenium and glutathione peroxidases in blood of patients with different stages of chronic renal failure. J Trace Elem Med Biol 2004;17:291-299.

49 Grzegorzewska A: Factors influencing survival of patients on regular dialysis treatment. Adv Clin Exp Med 2006;15:689-694.

50 Nakamoto H, Suzuki H: Hypoproteinemia in patients with diabetes undergoing continuous ambulatory peritoneal dialysis is attributable to high permeability of peritoneal membrane. Perit Dial Int 2003;23:72-78. 